\title{
Typification of seven names in Dioscorea (Dioscoreaceae) described by J.D. Hooker
}

\author{
Pagare R.S. ${ }^{1 *}$, Kishor K.C. ${ }^{1}$ \& W. Arisdason ${ }^{2}$ \\ ${ }^{1}$ Department of Life Sciences, School of Science, Sandip University, Nashik, Maharashtra - 422 213, India \\ ${ }^{2}$ Botanical Survey of India, southern Regional Centre, TNAU Campus, Lawley Road, Coimbatore, Tamil Nadu - 641 003, India \\ *E-mail: ravikiranpagare@gmail.com
}

\begin{abstract}
Nomenclatural notes on the species of Dioscorea L. described by J.D. Hooker in the Flora of British India are presented here. The study is based on the critical evaluation of all available original materials from various herbaria (BM, E, G, K, L, P and CAL). Lectotypes for seven names, viz. D. collettii Hook.f., $D$. gibbiflora Hook.f., D. jacquemontii Hook.f., D. laurifolia Wall. ex Hook.f., D. obcuneata Hook.f., D. polyclades Hook.f. and D. wightii Hook.f. are designated here.
\end{abstract}

Keywords: Flora of British India, Lectotype, Nomenclature, Original material, Syntype.

\section{Introduction}

Dioscorea L. is the largest genus in the family Dioscoreaceae, represented by c. 681 species worldwide (http://www. plantsoftheworldonline.org/). Hooker (1892) reported 25 species of Dioscorea in the Flora of British India, of which 14 are mentioned as imperfectly known and undeterminable species. According to him "The species of Dioscorea are in a state of indescribable confusion, and I cannot hope to have escaped errors in the determination and delimitation of the Indian ones, to which I have devoted much labour". Among the species of Dioscorea described by Hooker, ten are accepted as taxonomically distinct and one, viz. D. deflexa Hook.f. was treated as illegitimate heterotypic synonym because of the preoccupancy of $D$. deflexa Griseb., 1875. Among the ten valid names, three, viz. D. decipiens Hook.f., D. hamiltonii Hook.f. and D. wallichii Hook.f. have already been

Received: 17.12.2019; Revised \& Accepted: 12.06.2020

Published Online: 30.06.2020 lectotypified by Wilkin et al. (2007). The remaining seven accepted names are lectotypified here.

\section{Typification}

Dioscorea collettii Hook.f., Fl. Brit. India 6: 290. 1892. Lectotype (designated here): BURMA, Upper Burma, Shan Hills, Naungtaya, 4000 ft, ơ fl., May 1888, H. Collett 775 (K [K000098153 digital image!]; isolecto CAL [CAL0000024783!]).

Fig. 1

Notes: Collett and Hemsley (1890) recognized a new species of Dioscorea based on materials collected by Collett from Shan Hills, Burma (now Myanmar), and provided a brief description without naming. Hooker (1892) described it as D. colletii, and commented "the only Asiatic species with forked filaments and separated anther-cells". Two collections of Collett 775 (CAL0000024783!, K000098153 digital image!) annotated by J.D. Hooker were traced at CAL and K. Apart, one more specimen (Collett 781) was found at $\mathrm{K}$ (K001142113) from the same locality and all three specimens can be regarded as syntypes (Art. 9.4 of Shenzhen Code, Turland et al., 2018). Thapyai et al. (2005) treated the specimen (Collett 775) at K as holotype, however, since the collection number and housing of specimen mentioned neither by Collett nor by Hooker, this cannot be considered as holotype. Therefore, the specimen (K000098153, http://specimens.kew.org/herbarium/K000098153) in best agreement with the protologue and having an annotation of Collett and Hemsley (1890) as "Dioscorea sp. Indescript., Collett \& Hemsley in Journ. Linn. Soc. v 28. 137 (1890)” is designated here as the lectotype. 


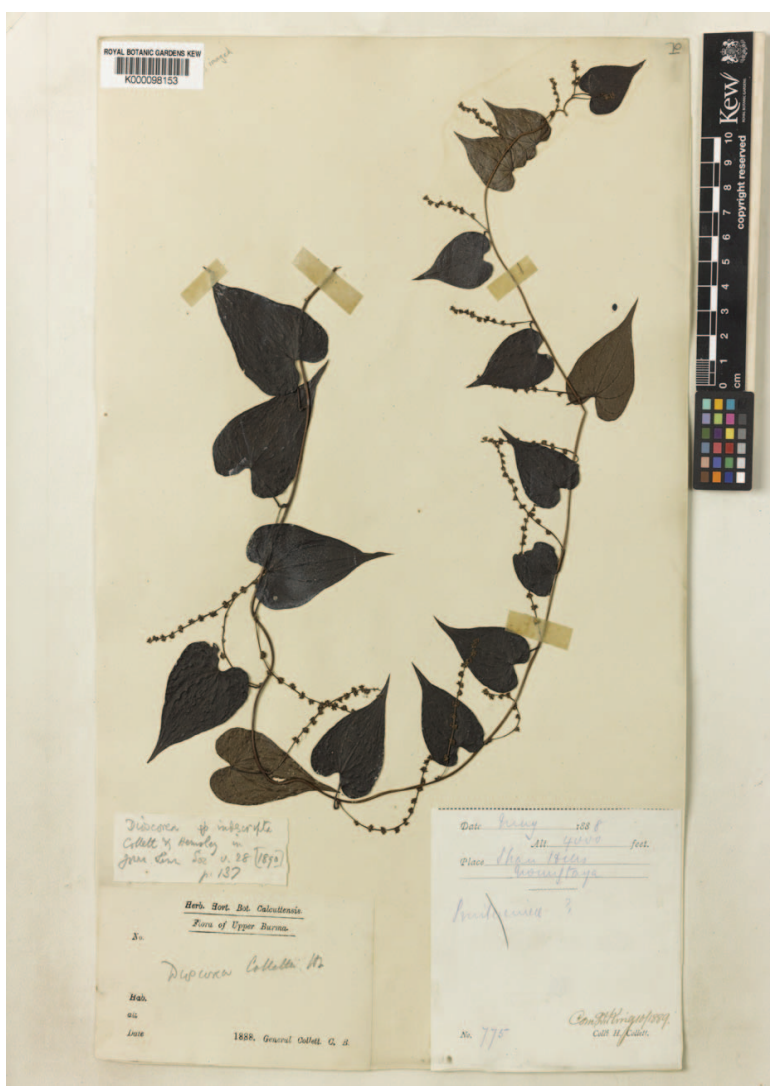

Fig. 1. Lectotype of Dioscorea collettii Hook.f. (http://specimens.kew.org/ herbarium/K000098153) (C) The Board of Trustees for The Royal Botanic Gardens, Kew. Reproduced with permission.

Dioscorea gibbiflora Hook.f., Fl. Brit. India 6: 294.1892. Lectotype (designated here): Penang, ơ fl., s.d., Wallich 5105B (K [K000098243 digital image!]; isolecto K [K000098242, K000098244, K000098245, K000098247 digital images!]).

Fig. 2

Notes: Hooker (1892) described D. gibbiflora based on a collection made by Wallich from Penang. Five Wallichian (5105B) specimens (K000098242, K000098243, K000098244, K000098245, K000098247) were traced at K. Except the specimen K000098247, all other specimens were annotated by Hooker as D. gibbiflora. Among them, K000098243 (http://specimens.kew.org/herbarium/ $\mathrm{K} 000098243$ ) is the most representative one and thus designated here as lectotype.

Dioscorea jacquemontii Hook.f., Fl. Brit. India 6: 290. 1892. Lectotype (designated here):INDIA, Between Poonah and Carli, ơ fl., s.d., Jaquemont 568 (K [K000950634 digital image!]).

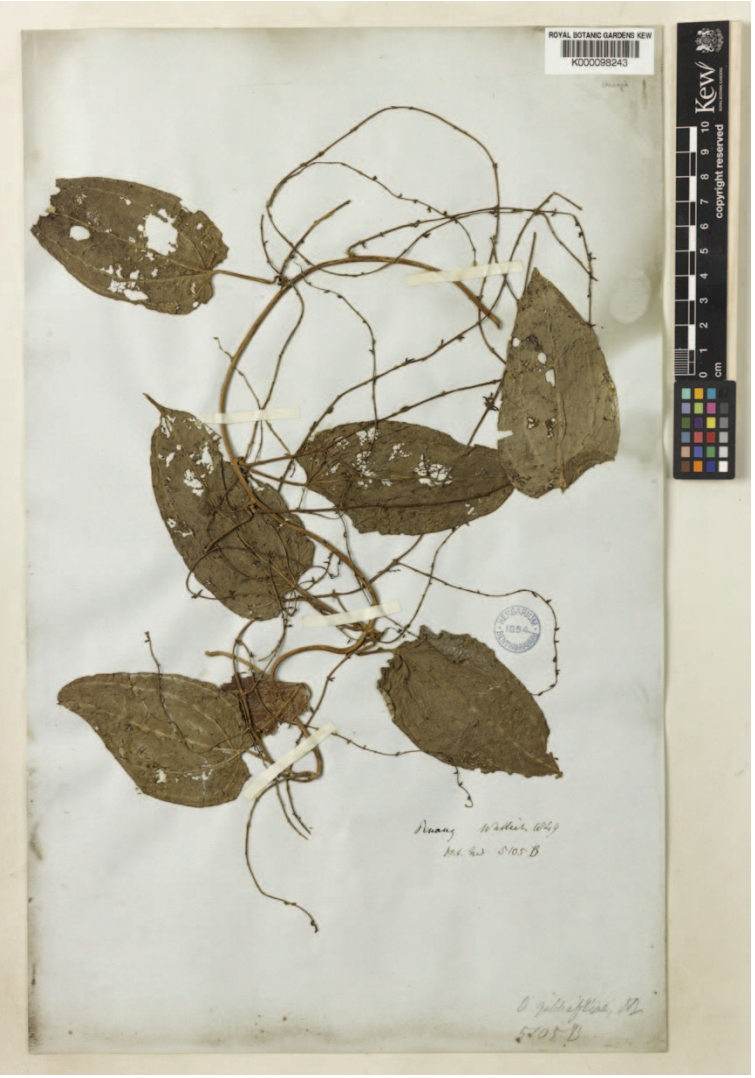

Fig. 2. Lectotype of Dioscorea gibbiflora Hook.f. (http://specimens. kew.org/herbarium/K000098243) (C) The Board of Trustees for The Royal Botanic Gardens, Kew. Reproduced with permission.

Notes: Hooker (1892) described D. jacquemontii based on the collections made by Jacquemont and Ritchie from Concan, between Poonah (Pune), Carli and Belgaum, respectively. Two sheets bearing the same field number, Ritchie 730 (K000950635, K000950636) were traced at K. The sheet bearing barcode K0009500635 is mounted with three female specimens, whereas, the sheet with barcode, K000950636, has one male and one female specimen. Furthermore, a sheet with two fertile specimens (Jacquemont 568), male (K000950634) and female (K000098193) collected by Jacquemont was traced at K. All the four sheets can be considered as syntypes according to Art. 9.6 of Shenzhen Code (Turland et al., 2018). Among them, Jacquemont 568 (K000950634, http:// specimens.kew.org/herbarium/K000950634), is the most complete representative and is designated here as the lectotype. 


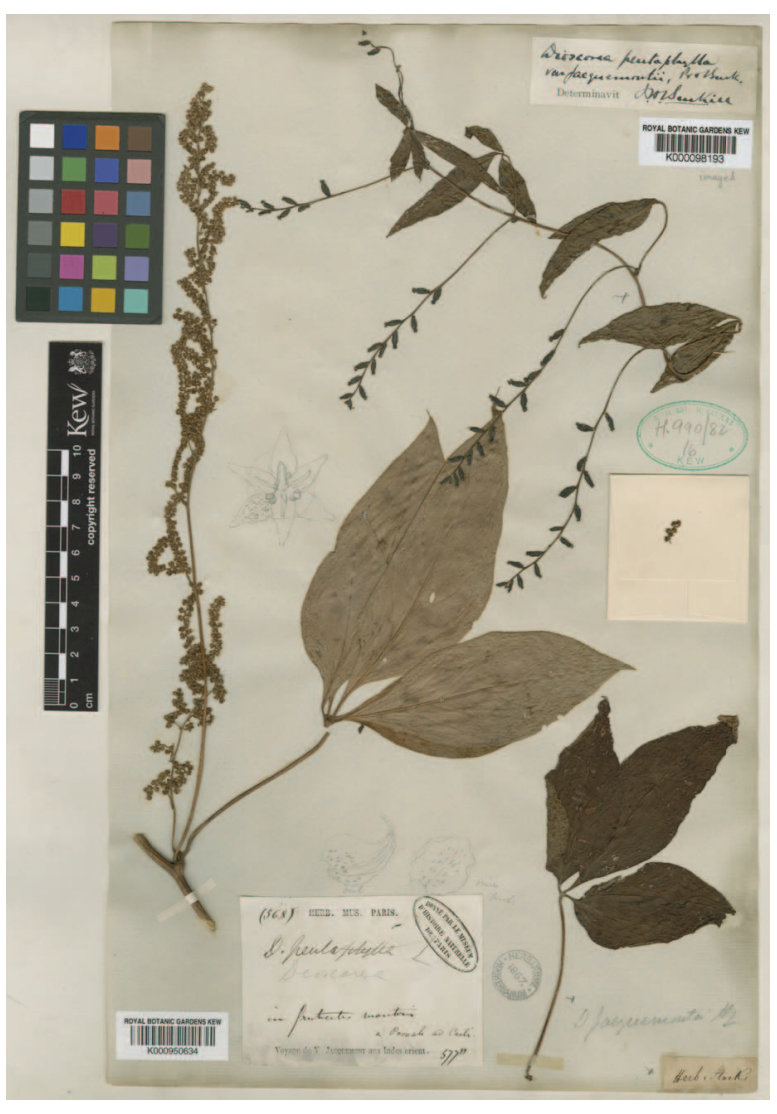

Fig. 3. Lecotype of Dioscorea jacquemontii Hook.f. (http://specimens. kew.org/herbarium/K000950634) (C) The Board of Trustees for The Royal Botanic Gardens, Kew. Reproduced with permission.

Dioscorea laurifolia Wall. ex Hook.f., Fl. Brit. India 6: 293.1892.

Lectotype (designated here): Penang, ơ fl., s.d., G. Porter s.n. (BM [BM001049925 digital image!]; isolecto K [K001104831, K000098237, K000098238 digital images!], CAL [Acc. No. 477394!]).

Fig. 4

Notes: Hooker (1892) validated D. laurifolia Wall. (Numer. List No. 5111, nom. nud.) and mentioned three collectors, viz. Porter, Maingay and Hullet in the protologue. Four sheets from Penang, Porter (Wall., Numer. List No. 5111) has been located, one at BM (BM001049925) and three at K (K001104831, K000098237, K000098238) and all can be regarded as syntypes (Art. 9.4, 9.6; Turland et al., 2018). Also, no collection under Maingay and Hullet is traceable in any of the herbaria. Furthermore, in synonymy, a collection from Penang by Porter is referred under D. glabra (Wall.,

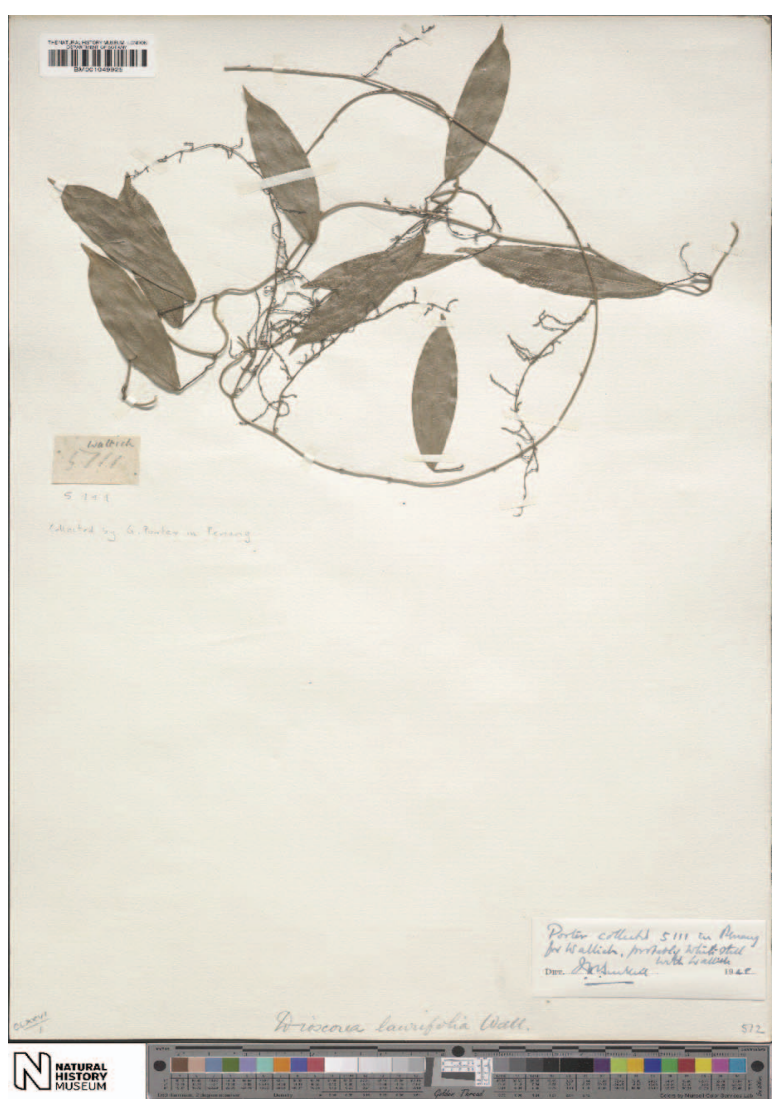

Fig. 4. Lectotype of Dioscorea laurifolia Wall. ex Hook.f. (https://data. nhm.ac.uk/dataset/collection-specimens/resource/05ff2255-c38a40c9-b657-4ccb55ab2feb/record/4544812) (C) The Natural History Museum, London. Reproduced with permission.

Numer. List No. 5105B). Three sheets have been traced under the name at BM and $K$ (BM001049881, K001104787, K001104788), but we could not recognize any elongated unilaterally panicled male spikes in the specimens which is one of the key characters of D. laurifolia. Hence, these are not considered under D. laurifolia here. Among the four recognized sheets, the specimen (BM001049925, https://data.nhm.ac.uk/dataset/ collection-specimens/resource/05ff2255-c38a40c9-b657-4ccb55ab2feb/record/4544812) with Porter's annotation best agrees with the protologue and is designated here as the lectotype and others consequently as isolectotypes.

Dioscorea obcuneata Hook.f., Fl. Brit. India 6: 293. 1892. Lectotype (designated here): CEYLON, s.l., ơfl., s.d., Macrae 111 (K [K000098236 digital image!]; isolecto BM [BM000958191 digital image!]). 
Notes: Hooker (1892) described D. obcuneata based on collection made from Ceylon (now Sri Lanka), but did not provide any details on specimen. However, Hooker (1892) had mentioned in the protologue that "he had seen one specimen in Hookerian Herbarium collected from Ceylon and annotated by Sir W. Hooker but with no other locality or collector's name". But, this specimen is not traceable in any of the herbaria. However, other two specimens were traced, one each at $\mathrm{K}$ (K000098236) and BM (BM000958191) for the name D. obcuneata. The specimen housed at $\mathrm{K}$ (K00008236) was annotated by Hooker and according to the article 9.6, the above specimens can be considered as syntypes. Among them, though both have distinct inflorescences, Macrae 111 housed at K (K000098236, http://specimens. kew.org/herbarium/K000098236) is the most complete specimen that shows phyllotaxy clearly is designated here as the lectotype.

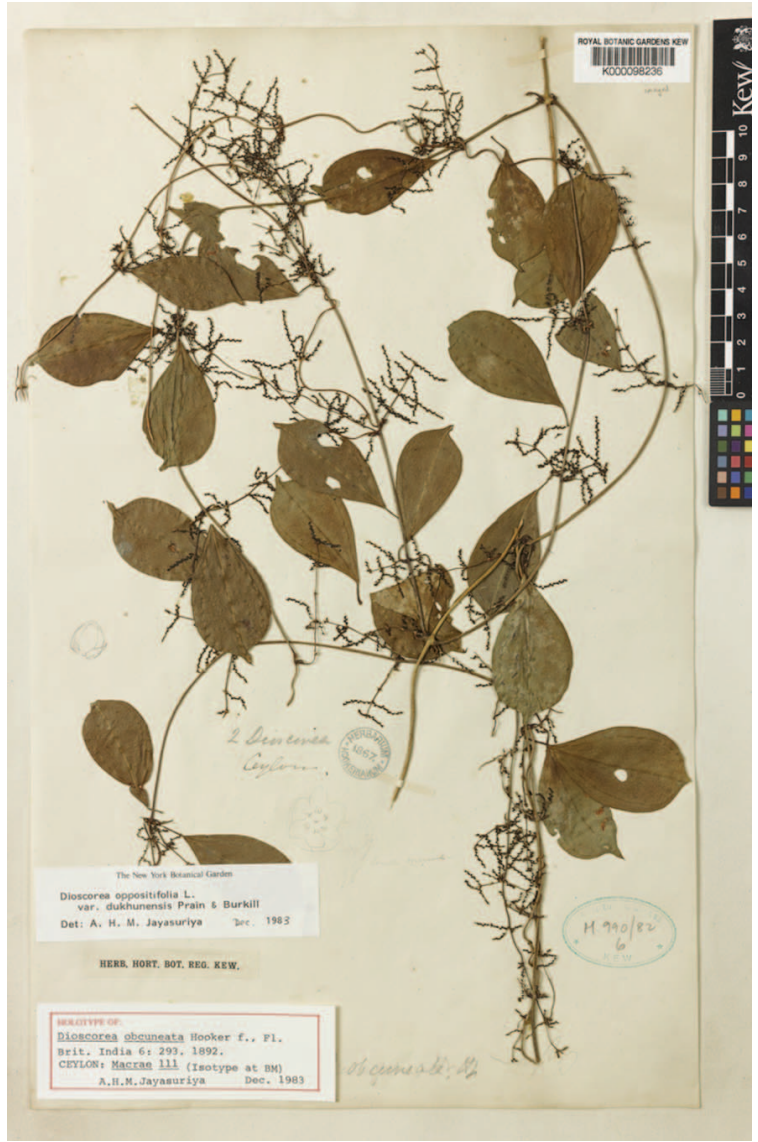

Fig. 5. Lectotype of Dioscorea obcuneata Hook.f. (http:// specimens.kew.org/herbarium/K000098236) @ The Board of Trustees for The Royal Botanic Gardens, Kew. Reproduced with permission.
Dioscorea polyclades Hook.f., Fl. Brit. India 6: 294. 1892. Lectotype (designated here): SINGAPORE, ơ fl., 1890, Ridley 1646 (BM [BM001051495 digital image!]).

Fig. 6

Notes: Hooker (1892) described D. polyclades based on collection made by Ridley from Singapore. Hooker (1892) had also stated "The Singapore plant I think certainly Zollinger's No. 283 from Java”. Eight specimens of Zollinger 283, two each at BM (BM001051499, BM001051500), G (G00191826, G00191835) and K (K000098332, K001144646) and one each at L (L 1465246) and P (P01751236) were traced. But Ridley 1646 at BM (BM001051495, https://data.nhm.ac.uk/object/ b56ec95e-6155-4b9a-a01e-89e3679b557f/ $1564358400000)$ is the sole collection which unequivocally agrees with the protologue is designated here as the lectotype.

Dioscorea wightii Hook.f., Fl. Brit. India 6: 291.

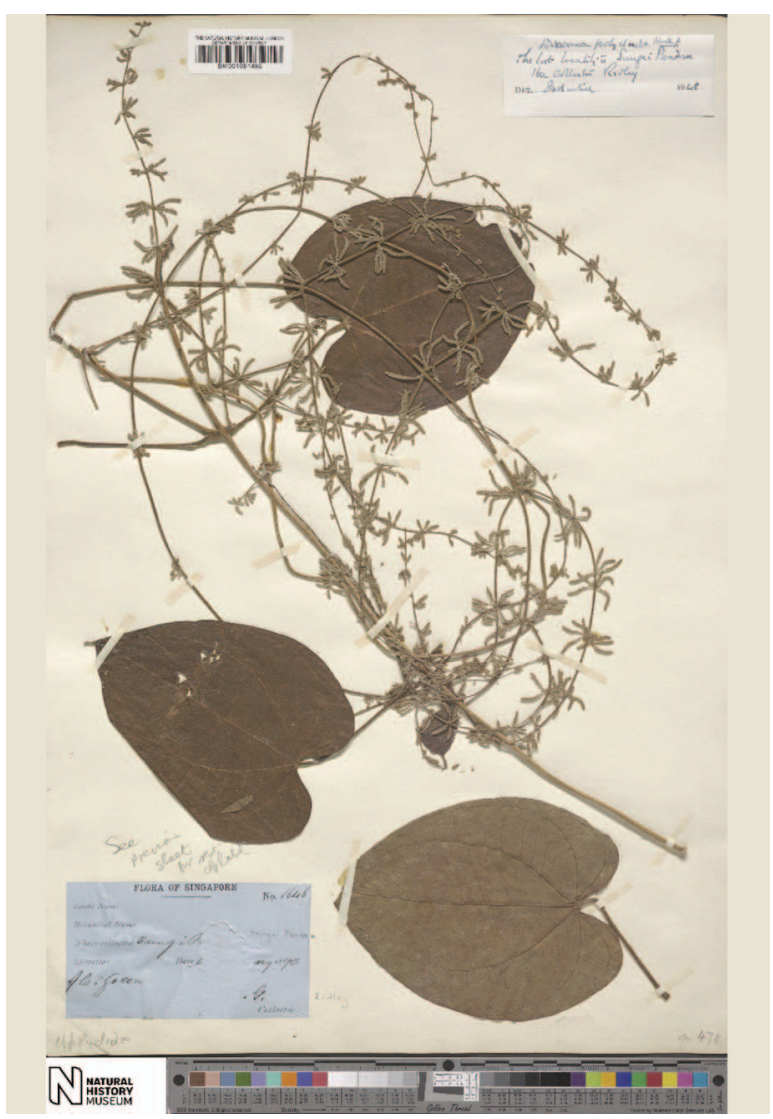

Fig. 6. Lectotype of Dioscorea polyclades Hook.f. (https:// data.nhm.ac.uk/object/b56ec95e-6155-4b9a-a01e-89e3679b557f/ 1564358400000) (C) The Natural History Museum, London. Reproduced with permission. 
1892. Lectotype (designated here, if not holotype): Travancore, Courtallam, August 1835, Wight 2827 (K [K000098200 digital image!]; isolecto CAL [CAL0000024785!]).

Fig. 7

Notes: Hooker (1892) described D. wightii based on collection made by Robert Wight from Courtallam, (in Tamil Nadu). Two collections (male specimens), Wight 2827 and Wight 939A, which are matching with the protologue were traced at K. Under the gathering Wight 2827, two herbarium sheets were traced, one each at $\mathrm{K}$ (K000098200) and CAL (CAL0000024785), however, only the $\mathrm{K}$ specimen was annotated by the author. The herbarium catalogue database of Royal Botanical Garden, Edinburgh indicates Wight 939A (E00179442 and E00179443) as isotypes. There is no evidence to prove which among the available specimens is seen by Hooker. Since the primary deposit of Hooker is at Kew, the specimen bearing the barcode K000098200 (http:// specimens.kew.org/herbarium/K000098200) is selected here as the lectotype.

\section{Acknowledgements}

The authors wish to thank the curators of BM, E, G, K, L and P for making the specimens available online, their responses over email and allowing us to reproduce them, and to CAL for rendering permission to consult. First author is thankful to Dr. K.N. Gandhi, Senior Nomenclatural Registrar, $\mathrm{HUH}$, Cambridge, for his suggestions on typification. KCK and RSP are thankful to DSTSERB (EEQ/2018/000289), for the financial support.

\section{Literature Cited}

COLLET B.G \& W.B. HEMSLEY 1890. On a collection of Plants from upper Burma and the Shan States. Botanical Journal of Linnaean Society 28: 1-10. https://doi.org/ 10.1111/j.1095-8339.1890.tb01452.x

HOOKER J.D. 1892: Dioscoreaceae. In: HOOKER J.D. (ed.), The flora of British India. Volume 6. L. Reeve \& Co., London. pp. 288-296.

McNEILL J. 2014. Holotype specimens and type citations: General issues. Taxon 63(5): 1112-1113. http:// dx.doi.org/10.12705/635.7

PRAIN D. \& I.H. BURKILL 1914. A synopsis of the

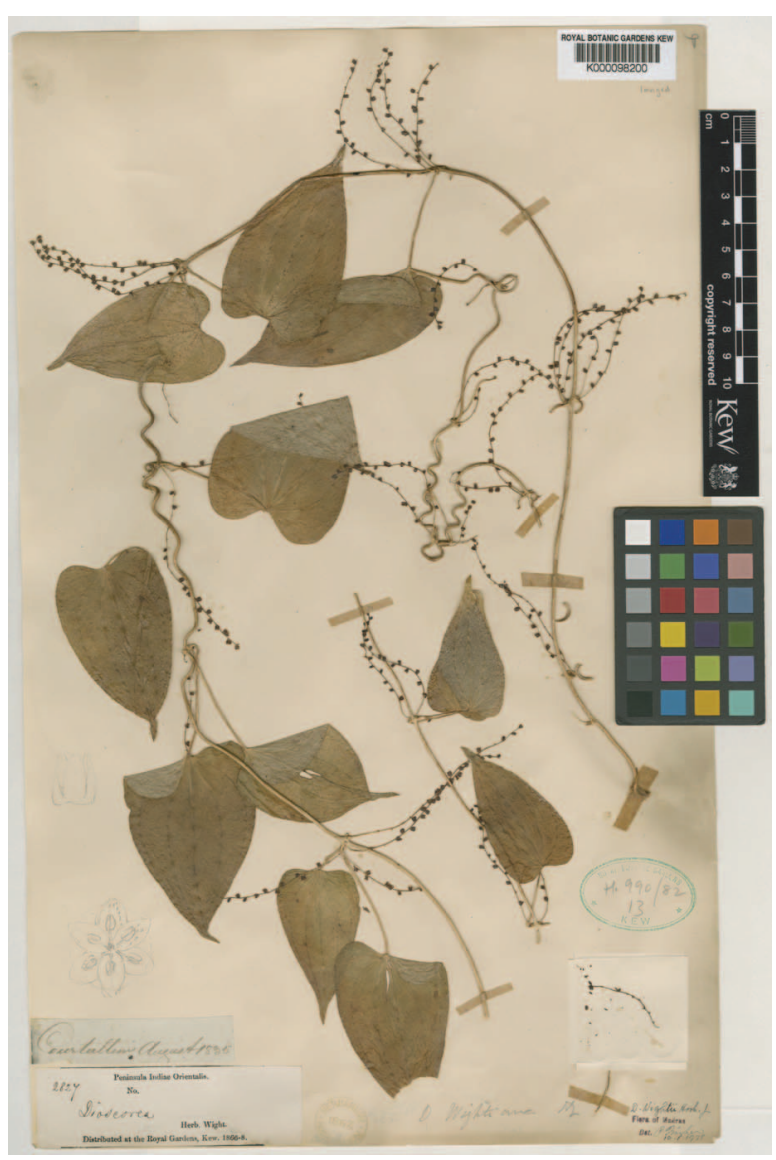

Fig. 7. Lectotype of Dioscorea wightii Hook.f. (http://specimens. kew.org/herbarium/K000098200) (C The Board of Trustees for The Royal Botanic Gardens, Kew. Reproduced with permission.

Dioscoreas of the Old World Africa excluded, with description of new species and varieties. Journal and Proceedings of the Asiatic Society of Bengal 10: 5-41.

THAPYAI C., WILKIN P. \& K. CHAYAMARIT 2005. The Dioscorea species of Doi Chiang Dao with particular reference to Dioscorea collettii Hook.f. (Dioscoreaceae), a new record from northern Thailand. Thai Forest Bulletin (Botany) 33: 213-219.

TURLAND N.J., WIERSEMA J.H., BARRIE F.R., GREUTER W., HAWKSWORTH D.L., HERENDEEN P.S., KNAPP S., KUSBER W.H., LI D.Z., MARHOLD K., MAY T.W., McNEILL J., MONRO A.M., PRADO J., PRICE M.J. \& G.F. SMITH (eds.) 2018. International Code of Nomenclature for algae, fungi, and plants (Shenzhen Code) adopted by the Nineteenth International Botanical Congress Shenzhen, China, July 2017. Regnum Vegetabile 159. Koeltz Botanical Books, Glashütten. https://doi.org/10.12705/ Code.2018

WILKIN P., THAPYAI C. \& K. CHAYAMARIT 2007. Lectotypification of Dioscorea L. (Dioscoreaceae) names from Thailand. Kew Bulletin 62(2): 251-257. https:// www.jstor.org/stable/20443349 